\title{
Systematic inventory of anuran species (amphibians) in three agro-industrial zones in the Southeast of Cote d'Ivoire
}

\author{
OUNGBE Kary Venance ${ }^{1 *}$, ADEBA Patrick Joël'2, BLAHOUA Kassi Georges ${ }^{1}$, N'DOUBA Valentin1 \\ ${ }^{1}$ Department of Biological Sciences, Laboratory of Hydrobiology, Faculty of Science and Technology, University of \\ Félix Houphoüet-Boigny, Abidjan, Côte d'Ivoire. \\ ${ }^{2}$ Centre Suisse de Recherche Scientifique, 01 BP 1303 Abidjan, Côte d'Ivoire \\ *Corresponding author: E-mail: oungbe@yahoo.fr (225) 07382114 / 02660276
}

Original submitted in on 20, June 2018. Published online at www.m.elewa.org on $30^{\text {th }}$ November 2018 https://dx.doi.org/10.4314/jab.v131i1.3

\begin{abstract}
Objective: The aim of this study was to make a systematic inventory of Anuran species in three agroindustrial zones of South-East Côte d'lvoire, with a view to making a contribution to the knowledge of amphibians in Côte d'Ivoire.

Method and Results: Anurans were captured using catch boxes and dip nets. Species identification was done using the determination keys proposed by Rödel (2000a) and Frétey et al. (2011). Twenty-eight (28) species belonging to 12 genus and 10 families have been inventoried. The family Ptychadenidae is the most diversified with 6 species. They are followed by Hyperoliidae and Phrynobatrachidae both having 5 species each. Arthroleptidae and Bufonidae contain 4 species and 3 species respectively. Dicroglossidae, Hemisotidae, Pipidae, Pyxicephaliidae and Ranidae are the least diversified with one (1) species each. Three unidentified species have also been inventoried: Artroleptis sp, Sclerophrys sp and Phrynobatrachus sp. It appears also 6 species are common to all the three plantations while 1, 4 and 8 species are specific to coconut plantation, palm plantations and banana plantations respectively.

Conclusion and application: This study has made it possible to make a qualitative inventory of the Anura in three Agro-industrial zones of the South-eastern Côte d'Ivoire. These results will serve as a reference for further investigations of the amphibians and the development of appropriate measures to ensure better protection and sustainable exploitation of Anuras in Côte d'Ivoire.

Keywords: Anurans, qualitative inventory, diagnosis, agro-industrial zone, Côte d'Ivoire.
\end{abstract}

\section{INTRODUCTION}

Anuran are the most diversified Amphibians or Batrachians in the world (Lecointre and Le Guyader, 2006). They are grouped into 55 families divided into 451 genus and making a total of 6968 species (www.amphibiaweb.org, 2018). They are toads, frogs and tree frogs. They live a double life. They live in water on one hand and on the other hand on land, that is terrestrial life (Lecointre and
Le Gouyader, 2006). These animals are of paramount importance to humans in both food and economic terms (Channing, 2001). In terms of food, some species of Anurans are a very good source of animal protein. As a result, they have a very important commercial value (Neveu 2004, Nzigidahera 2005). In Côte d'Ivoire, the species Hoplobatrachus occipitalis constitute a source of 
protein that is highly valued to certain population of Western Côte d'lvoire, especially the Yacouba, Guéré and Wobe (Blé et al., 2016). There thighs are sold in several areas namely markets, restaurants and even supermarkets. In addition, Anurans arouse a fundamental interest to farmers because of their diet. They consume invertebrates in general and insects in particular (Konan et al., 2016), which makes them, organisms likely to reduce the rates of insects' known to be destroyers of plantations and thereby participate in the increase of farm yields (Channing, 2001). Moreover, Anurans are not absolved from the harmful effects of agricultural practices. The use of Pesticide is a common practice that negatively affects Anuran population (Bridges and Semlitsch 2000, Semlitsch 2000). These farming practices modify the habitats, the species richness and the feeding habits of these animals by not giving them the opportunity to choose and feed on their prefered prey (Hoyos-Hoyos et al., 2012, Menin et al., 2015). In the face of these threats, an

\section{MATERIAL AND METHODS}

Study Area: This study was conducted in three large plantations in south-eastern Côte d 'Ivoire (Figure 1). These are the coconut plantations in Grand-Bassam (5 - $12^{\prime} \mathrm{N}, 3^{\circ} 45^{\prime} \mathrm{W}$ ), the palm tree plantations in Toumanguie / N'Zikro $\left(5^{\circ} 23^{\prime} \mathrm{N}, 3^{\circ} 24^{\prime} \mathrm{W}\right)$ and the Banana plantations in Akressi $\left(5^{\circ} 41^{\prime} \mathrm{N} ; 3^{\circ} 05^{\prime} \mathrm{W}\right)$. The study area is located between $5^{\circ} 10$ 'and $5^{\circ} 50^{\prime}$ north latitude and $3^{\circ}$ and $3^{\circ} 50$ 'west longitude. The choice of sites was made due to accessibility, availability and especially the presence of a wetland (pond) in each plantation. The coconut groves in Grand-Bassam are characterized by the presence of water in a temporary way whereas the palm plantations in Toumanguie and the banana plantations in Akressi are characterized by the presence of water permanently.

Anuran sampling and identification: Anuran sampling was conducted monthly from November 2016 to October 2017 with a frequency of two days in each plantation. The duration of this hunting activity was two investigation on the batrachofauna in these areas is necessary. This will elaborate adequate measures to ensure a better protection and a durable exploitation of Anurans. In Côte d'Ivoire, several surveys have been carried out on the diversity of the Anuran population. Most of these surveys have been carried out in protected areas (Rödel and Spieler 2000, Rödel 2000b, Rödel and Branch 2002, Rödel 2003, Rödel and Ernest 2003, Rödel and Ernest 2004, and Adeba et al., 2010). In the south-east of Côte d'Ivoire, studies on the biodiversity of Anuran population have been undertaken in primary tropical moist forests, in this case the Banco National Park (Assemian et al., 2006), the marshes forest Tanoé-Ehy (Kpan et al., 2014) and a village forest in Yakassé-Mé (Kouamé et al., 2014). Studies of the batrachofauna in agricultural and urban areas (Kouamé et al., 2015) remain very rare or non-existent. The present study aimed at making the first systematic inventory of Anuran in three agro-industrial zones of South-East Côte d'Ivoire.

hours with the same hunting efforts. The method used for sampling was the visual collection method (Rödel and Ernest, 2004). The team consisted of two or three people, walked in the plantation without following a specific direction and captured with the help of catching-box and scoop net, Anouran alive and visible in a given site. This method was used both during daytime sampling (6h to $8 \mathrm{~h}$ ) and evening sampling (19h to $21 \mathrm{~h}$ ). This time schedule has been described by Tohé et al. (2008) because during this period of the day, the Anuras croaking activity is intense and the daylight brightness is low. During the evening sampling a flashlight was used to enable locating the animals. The Anuras, dazzled by the light beam of the torch were immobilized and thus captured easily alive. The captured animals were identified using Rödel's determination keys (2000a) and Frétey et al. (2011) and information such as: Sex and snout-vent length (SVL) were recorded for each individual animal. 


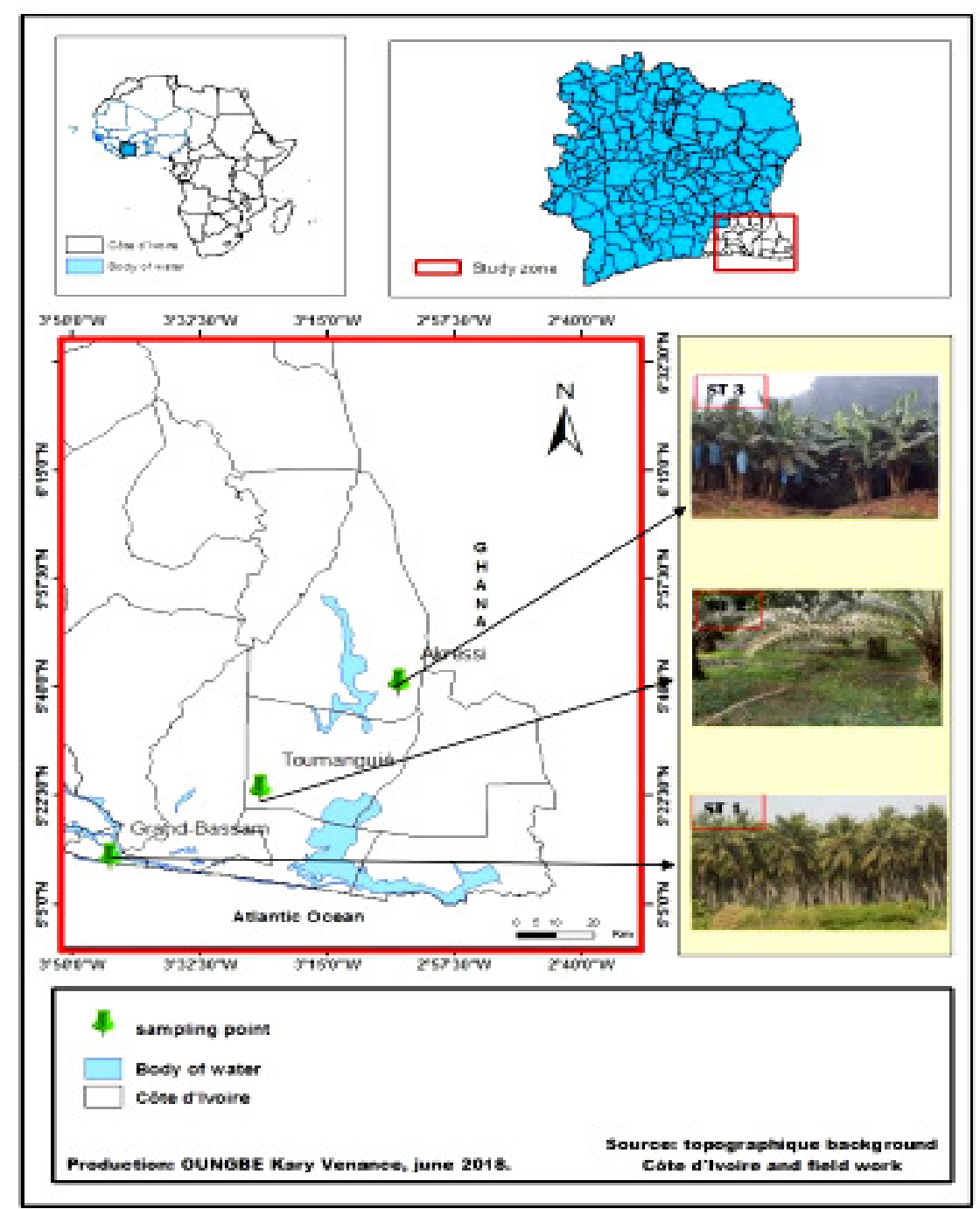

Figure 1 : location of the different agro-industrial zones sampled

ST 1 : Coconut Plantation ; ST 2 : Palm Plantation ; ST 3 : Banana Plantation

\section{RESULTS AND DISCUSSION}

Inventory: The results of the qualitative Anuran inventory in three agro-industrial zones in South-East Côte d'lvoire are presented in a condensed form in Table 1. A total of 28 species divided into 12 genus belonging to 10 families were recorded in all sampled areas. The most diversified family is Ptychadenidae with 6 species. They are followed by Hyperoliidae and Phrynobatrachidae both having 5 species each. Arthroleptidae and Bufonidae comprising respectively 4 species and 3 species. Dicroglossidae, Hemisotidae, Pipidae, Pyxicephaliidae and Ranidae are the least diversified with one (1) species each. Three unidentified species have also been inventoried: Artroleptis $s p$, Sclerophrys sp and Phrynobatrachus sp. The total number of Anuran species (28 species) is not exhaustive given that not all the areas of the different plantations were sampled and only one sampling method "visual sampling method" was used for the systematic inventory of Anurans. However, compared to the Banco National Park with 28 species (Assemian et al., 2006) and a village forest of Yakassé-Mé with 24 species (Kouamé et al., 2014), the number of species found in this study is considerable (Anuran species inventoried in the South East of Côte d'Ivoire). In the coconut plantation in Grand-Bassam 10 species, in the palm groves in Toumanguie 18 species and in the banana plantations in Akressi 20 species have been listed. In view of these results, it appears that six 

industrial zones in the Southeast of Cote d'Ivoire.

species (Sclerophrys maculatus, Hoplobatrachus occipitalis, Afrixalus dorsalis, Hyperolius concolor, Ptychadena mascareniensis, P. pumilio) are common to all the three plantations while (Phrynobatrachus calcaratus), four spécies (Arthroleptis poecilonotus, Arthroleptis sp, Leptopelis viridis, Hemisus marmoratus) and eight spécies (Leptopelis macrotis, Sclerophrys sp, Afrixalius vittiger, Hyperolius fusciventris burtoni, Phrynobatrachus liberiensis, Ptychadena bibrioni, Aubria subsigillata, Amnirana albolabris) are specific to coconut plantation, palm plantations and banana plantations respectively.

Table 1: List of Anuran species found in three plantations in South-East Côte d'Ivoire

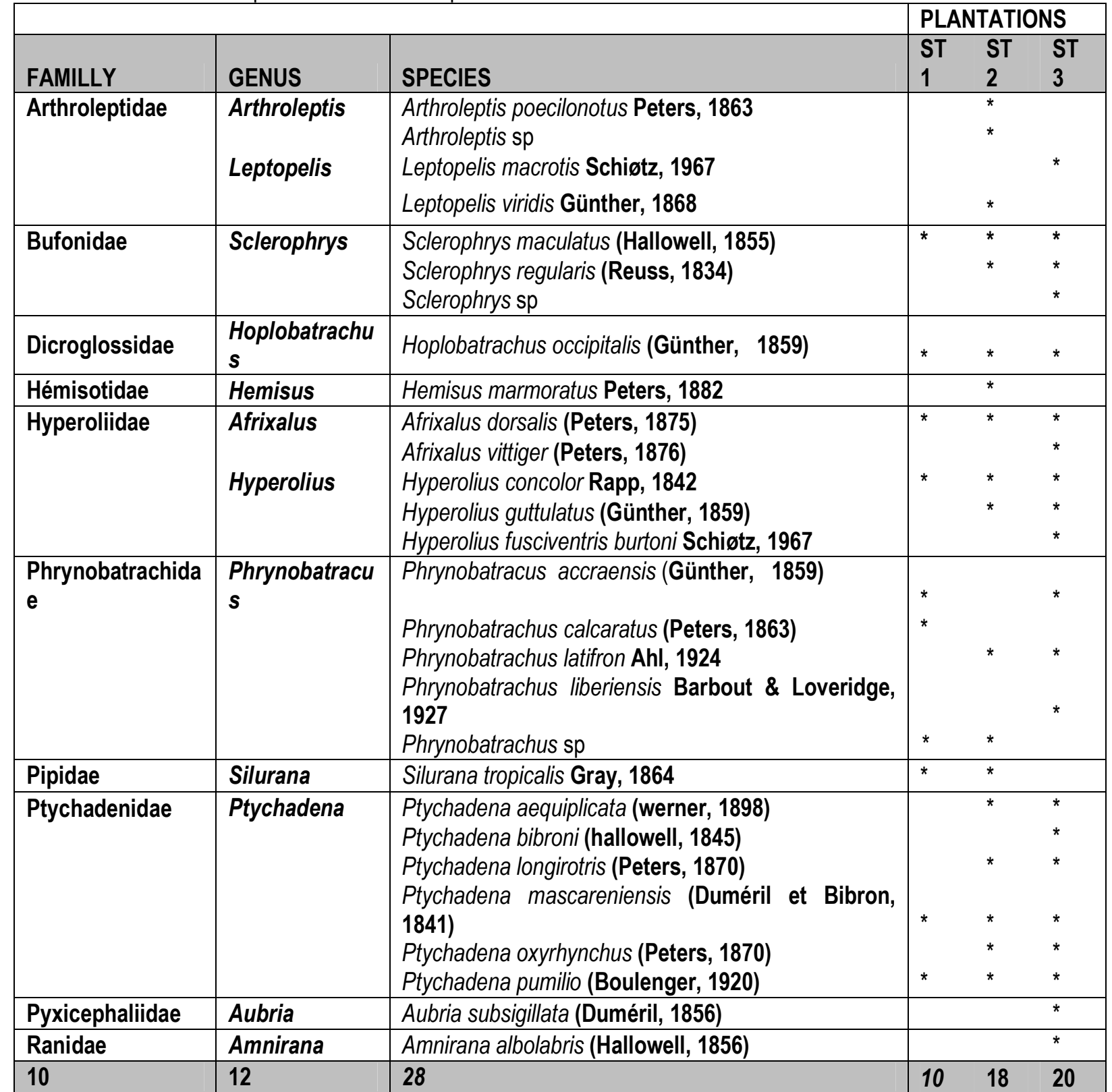

ST 1 = Coconut plantation ; ST 2= Palm plantation ; ST 3= banana plantation ; * = present

The qualitative analysis of Anuran populations in coconut plantations in Grand-Bassam, Palm plantation in Toumanguié and Banana plantation in Akressi has shown that there is a specific diversity of the animal population in the wet habitat. Indeed, the presence of rivers, streams, and ponds around the plantations 
creates favorable conditions for the growth of Anurans. The low number of species observed in the coconut plantations in Grand-Bassam (10 species) is due to the virtual absence of permanent water points in these zones. The largest number of species (20 and 18) recorded in the Banana plantations in Akressi and the Palm plantation in Toumanguié respectively can be explained by the permanent presence of water bodies in these areas and humid primary forests close to the plantations. Therefore, that explained the presence of the following Silurana tropicalis (aquatic frog), Aubria subsigillata (swamp species), Amnirana albolabris, Hyperolius fusciventris, Hemisus marmoratus (found mostly by the stream banks) and Leptopelis macrotis, $L$. viridis, Phrynobatrachus liberisis (wet primary forest species). Our observations are in agreement with that of Sinsch (1991) and Vallan (2000) who made known that the permanent presence of water points in an environment is essential for reproduction and determine their spatial distribution. Species such as: Sclerophrys maculatus, Hoplobatrachus occipitalis, Afrixalius dorsalis, Hyperolius concolor, Ptychadena mascareniensis and P. pumilio, picked in all plantations are cosmopolitan species. Indeed, these species have been described by Rödel (2000b) as typical Anurans in savannah areas and degraded habitats. These species have therefore developed coping strategies to survive in man-disturbed environments.

Diagnosis: At the end of the various observations and identifications, the families, genus and the species were grouped in alphabetical order and each species is briefly described (morphometric and meristic characteristics). The photos of the different taxa are also presented (Figure 2). 
Oungbe et al., J. Appl. Biosci. 2018 Systematic inventory of anuran species (amphibians) in three agro-industrial zones in the Southeast of Cote d'Ivoire.

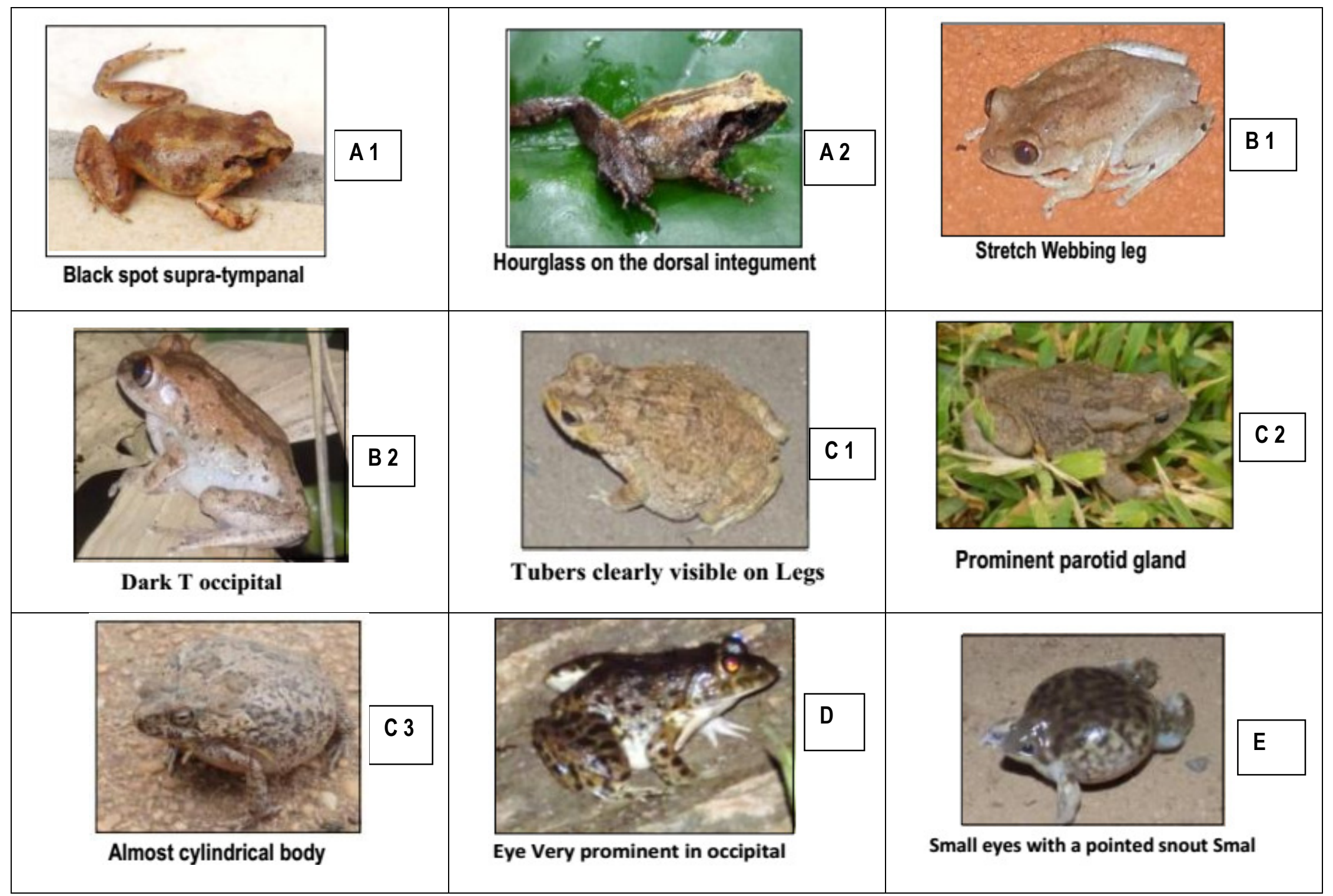


Oungbe et al., J. Appl. Biosci. 2018 Systematic inventory of anuran species (amphibians) in three agro-industrial zones in the Southeast of Cote d'Ivoire.

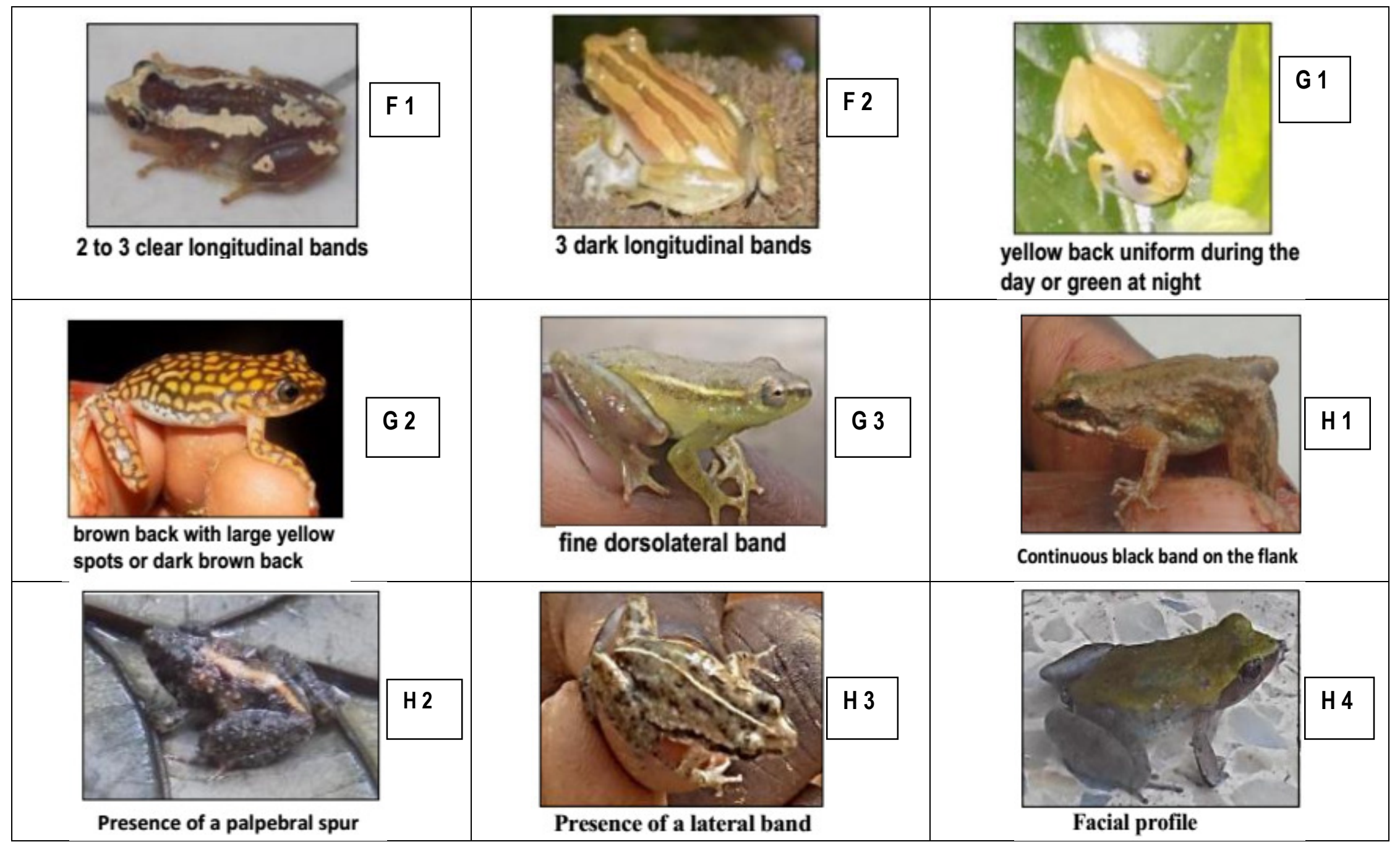


Oungbe et al., J. Appl. Biosci. 2018 Systematic inventory of anuran species (amphibians) in three agro-industrial zones in the Southeast of Cote d'lvoire.

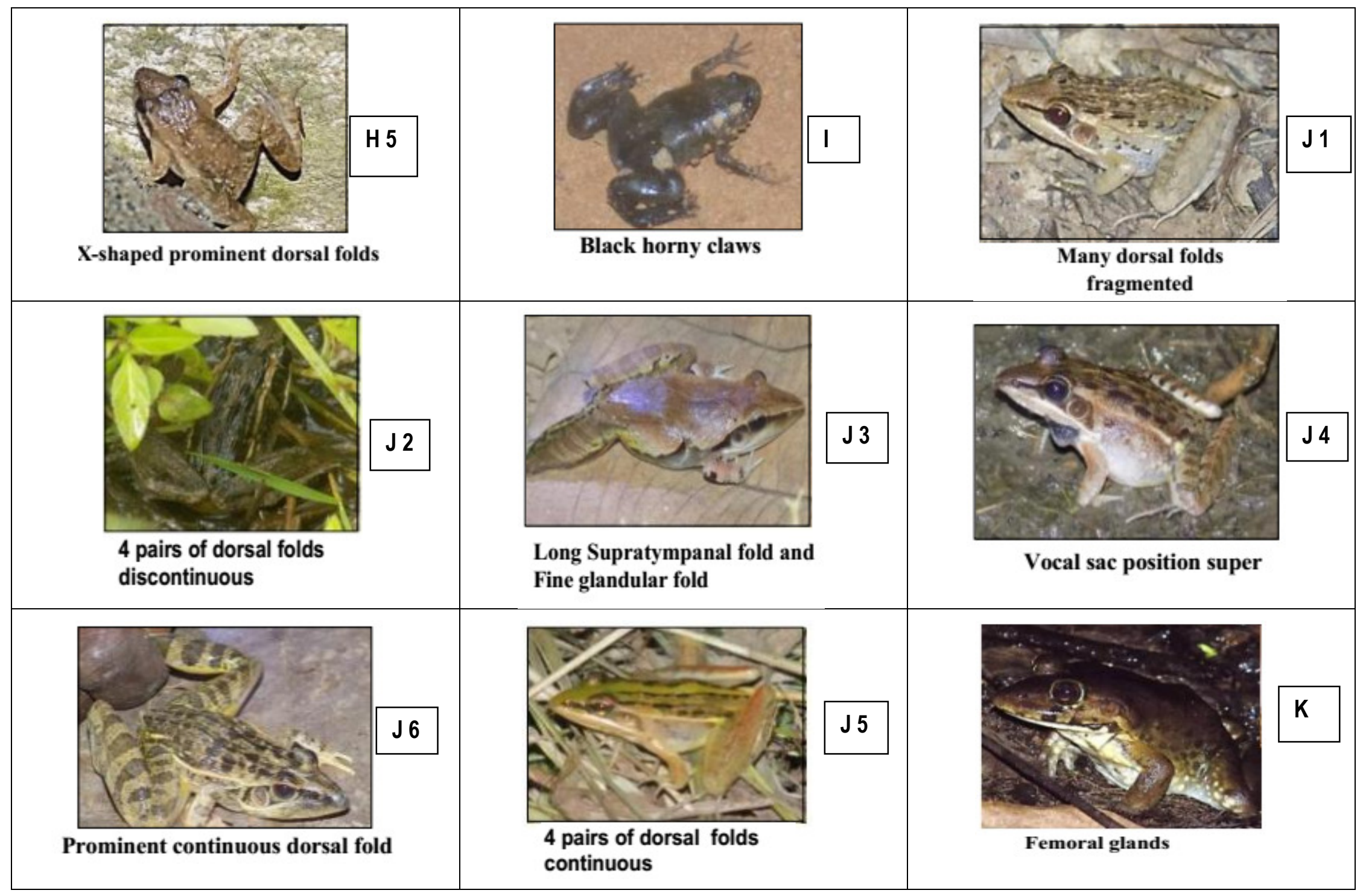




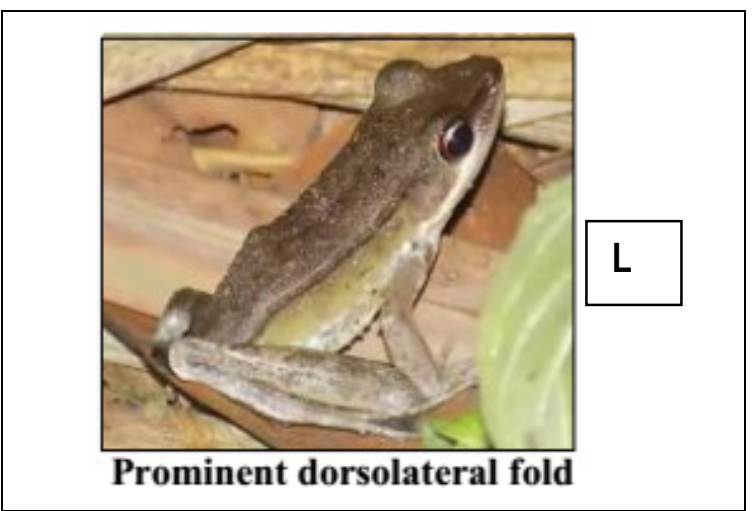

Figure 2: Photos of the different taxa of anuran in three agro-industrial zones in the Southeast of Cote d'Ivoire

A 1: Arthroleptis poecilonotus Peters, 1863, A 2 : Arthroleptis sp1, B 1 : Leptopelis macrotis Schiøtz, 1967, B 2 : Leptopelis viridis Günther, 1868, C 1 : Sclerophrys maculatus (Hallowell, 1855), C 2 : Sclerophrys regularis (Reuss, 1834), C 3 : Sclerophrys sp, D : Hoplobatrachus occipitalis (Günther, 1859), E : Hemisus marmoratus Peters, 1882, F 1 : Afrixalus dorsalis (Peters, 1875), F 2 : Afrixalus vittiger (Peters, 1876), G 1 : Hyperolius concolor Rapp, 1842, G 2 : Hyperolius guttulatus (Günther, 1859), G 3 : Hyperolius fusciventris burtoni Schiøtz, 1967, H 1 : Phrynobatracus accraensis (Günther, 1859), H 2 : Phrynobatrachus calcaratus (Peters, 1863), H 3 : Phrynobatrachus latifron Ahl, 1924, H 4 : Phrynobatrachus liberiensis Barbout \& Loveridge 1927, H 5 : Phrynobatrachus sp, I : Silurana tropicalis Gray, 1864, J 1 : Ptychadena aequiplicata (werner, 1898), J 2 : Ptychadena bibroni (Hallowell, 1845), J 3 : Ptychadena longirotris (Peters, 1870), J 4 : Ptychadena mascareniensis (Duméril and Bibron, 1841), J 5 : Ptychadena oxyrhynchus (Peters, 1870), J 6 : Ptychadena pumilio (Boulenger, 1920), K : Aubria subsigillata (Dumeril, 1856), L : Amnirana albolabris (Hallowell, 1856) 

industrial zones in the Southeast of Cote d'Ivoire.

Family Arthroleptidae Mivart, 1869

Genus Arthroleptis Smith, 1849

Arthroleptis poecilonotus Peters, 1863 (Figure 2 : A 1)

This species is characterized by a tympanum representing approximately $1 / 2$ of the diameter of the eye, a finely granular dorsal integument and a supratympanal black spot. The Snout-Vent Length (SVL) is 27.3 to $32 \mathrm{~mm}$ in the male $(\hat{O})$ and 25.7 to $35 \mathrm{~mm}$ in the female (ㅇ).

Arthroleptis sp1 (Figure 2 : A 2)

Morphologically closer to Arthroleptis poecilonotus, this species has a short third finger and the presence of the hourglass pattern on the dorsal integument. The SnoutVent Length (SVL) is 18 to $21.9 \mathrm{~mm}$ in the male $\left({ }^{1}\right)$ and 18.6 to $30 \mathrm{~mm}$ in the female (ㅇ).

\section{Genus Leptopelis Günther, 1859}

Leptopelis macrotis Schiøtz, 1967 (Figure 2 : B 1)

This taxon has extensive pediculated webs, a white belly with dark patterns. The Snout-Vent Length (SVL) is $48.8 \mathrm{~mm}$ in the female ( $($ ). A specimen was found in the banana plantations in Akressi.

Leptopelis viridis Günther, 1868 (Figure 2 : B 2)

This species has free fingers, a brown or gray dorsal surface with a dark triangle or dark occipital $T$ on the eyelids, a series of very variable spots, hind limbs have transverse bars. The Snout-Vent Length (SVL) is 51.45 $\mathrm{mm}$ in the female ( $($ ) . A specimen was observed in the Palm plantations in Toumanguié / N'Zikro.

Family Bufonidae Gray, 1825

Genus Sclerophrys Tschudi,1838

Sclerophrys maculatus (Hallowell, 1855) (Figure 2 : C 1)

Characterized by flat and poorly bounded parotid glands with distinct warts, the webbed toes are clearly visible with protuberances on the webbed toes, many tubercles are visible on the feet and the vocal sac with only one mouth opening. The Snout-Vent Length (SVL) is 26 to $54.6 \mathrm{~mm}$ in the male ( ${ }^{\text {) }}$ ) and 30.18 to 58.35 $\mathrm{mm}$ in the female (i).

Sclerophrys regularis (Reuss, 1834) (Figure 2 : C 2)

This taxon has parotid glands protruding and well bounded more or less smooth with warts indistinct, a vocal sac with two mouth openings. The Snout-Vent Length (SVL) is 52.6 to $62.6 \mathrm{~mm}$ in the male ( $\left.{ }^{\lambda}\right)$ and 58.35 to $70.3 \mathrm{~mm}$ in the female ( $(+)$.

Sclerophrys sp (Figure 2 :C 3)

This species is characterized by more or less smooth parotid glands and an almost cylindrical body. The Snout-Vent Length (SVL) is $60.5 \mathrm{~mm}$ in the male ( $)$. A specimen was identified in the Banana plantation Akressi.

Family Dicroglossidae Anderson, 1871

Genus Hoplobatrachus Peters, 1863

Hoplobatrachus occipitalis (Günther, 1859) (Figure 2 :D)

The characteristic of this taxon it has very visible eyes in the dorsal (occipital) position. The Snout-Vent Length (SVT) is 56.4 to $107 \mathrm{~mm}$ in the male ( $\hat{0}$ ) and 41.4 to $135.5 \mathrm{~mm}$ in the female (q).

\section{Family Hemisotidae Cope, 1867 \\ Genus Hemisus Günther, 1859}

Hemisus marmoratus Peters, 1882 (Figure 2 : E)

This plump, almost cylindrical species has a pointed snout, two small, barely visible eyes, and a highly developed internal metatarsal tubercle. The Snout-Vent Length (SVL) is $51.5 \mathrm{~mm}$ in the female (P). A specimen was found in the palm plantation in Toumanguie $/$ N'Zikro.

\section{Family Hyperoliidae Lawrence, 1943}

Genus Afrixalus Laurent, 1944

Afrixalus dorsalis (Peters, 1875) (Figure 2 : F 1)

This species is characterized by the presence of 2 to 3 clear longitudinal bands on the back with a pupil in vertical position, the male has an orange-colored throat. The Snout-Vent Length (SVL) is 18.17 to $31.5 \mathrm{~mm}$ in the male $(\hat{O})$ and 22.62 to $30.4 \mathrm{~mm}$ in the female (P).

Afrixalus vittiger (Peters, 1876) (Figure 2 : F 2)

This taxon has 3 dark longitudinal bands on the back forming a triangle above the head, an absence of vomerine teeth. The snout-vent length (SVL) is 22.35 $\mathrm{mm}$ in the male $(\hat{O})$. A specimen was found in the banana plantations in Akressi.

Genus Hyperolius Rapp, 1842

Hyperolius concolor Rapp, 1842 (Figure 2 : G 1)

This species is characterized by a slender body, a vocal sac with a small gular disk, a yellow back uniform during the day or green at night with tiny dark spots. The Snout-Vent Length (SVL) is 21.39 to $26.3 \mathrm{~mm}$ in the male ( $($ ) and 21.5 to $35 \mathrm{~mm}$ in the female (Q).

Hyperolius guttulatus (Günther, 1859) (Figure 2 : G 2)

This taxon has a rugged body, a vocal sac with a large gular disc, a brown back with large yellow spots or dark brown back with several diffuse orange dots, The Snout-Vent Length (SVL) is 27.9 to $37.7 \mathrm{~mm}$ in the

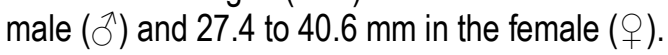



industrial zones in the Southeast of Cote d'Ivoire.

Hyperolius fusciventris burtoni Schiøtz, 1967 (Figure 2 : G 3)

The peculiarity of this taxon is the fine dorsolateral band. The back is green or beige with often a black vertebral line without drawing of the hourglass, clear flank and belly. The Snout-Vent Length (SVL) is 25.5 $\mathrm{mm}$ in the male $(\hat{)})$. A specimen was picked in the banana plantations in Akressi.

\section{Family Phrynobatrachidae Lawrence, 1941}

Genus Phrynobatracus Günther, 1862

Phrynobatracus accraensis (Günther, 1859) (Figure 2 : H 1)

This species is characterized by a continuous black band on the flank (from the eye to the hip), a yellow vocal sac in the male, large discs at the ends of the toes. The Snout-Vent Length (SVL) is 16.51 to $20.1 \mathrm{~mm}$ in the male $\left({ }^{1}\right)$ and 17.7 to $25.3 \mathrm{~mm}$ in the female (P). Phrynobatrachus calcaratus (Peters, 1863) (Figure 2 : H 2)

This taxon is characterized by the presence of reduced webs reaching only the first phalanx, a presence of a palpebral spur. The Snout-Vent Length (SVL) is 18.3 $\mathrm{mm}$ in the male ( $\left.{ }^{\Uparrow}\right)$. A specimen was observed in the coconut plantations in Grand Bassam.

Phrynobatrachus latifron Ahl, 1924 (Figure 2: H 3)

This species is distinguished by the presence of a pointed muzzle and a lateral dorsal band. The SnoutVent Length (SVL) is 18.8 to $20.3 \mathrm{~mm}$ in the male ( $\widehat{0})$ and 17.7 to $21.85 \mathrm{~mm}$ in the female (P). Phrynobatrachus liberiensis Barbout \& Loveridge 1927 (Figure 2 : H 4)

The face profile is dark (from the tip of the muzzle to the supra tympanal fold), many white dots on the dorsal surface. The Snout-Vent Length (SVL) is $36.5 \mathrm{~mm}$ in the female (P). A specimen was observed in the banana plantations in Akressi.

\section{Phrynobatrachus sp (Figure 2 : H 5)}

This species is characterized by prominent dorsal dermal folds protruding in the form of $X$ behind the orbits, the pedaling webs is well developed. The SnoutVent Length (SVL) is 16.5 to $18 \mathrm{~mm}$. The Sex could not be identified.

\section{Family Pipidae Gray, 1825}

\section{Genus Silurana Gray, 1864}

Silurana tropicalis Gray, 1864 (Figure 2 : I)

This taxon has webs at the ends of its limbs, three toes with metatarsal tubercles and black horny claws, tentacles under the ocular shorter than half the diameter of the eye and two rows of dorsal bulges. The Snout-Vent Length (SVL) is 40.9 to $48.6 \mathrm{~mm}$ in the

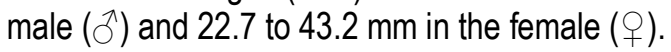

\section{Family Ptychadenidae Dubois, 1987}

Genus Ptychadena Boulenger, 1917

Ptychadena aequiplicata (werner, 1898) (Figure $2: \mathrm{J}$ 1)

This species is characterized by several fragmented dorsal folds, the second fold is interrupted at several levels, the supratympanal fold does not merge with the dorsolateral fold, an absence of sacral fold. The Snout Vent Length (SVL) is 35.1 to $45.2 \mathrm{~mm}$ in the male ( $\left.\sigma^{\pi}\right)$ and 30.9 to $50.6 \mathrm{~mm}$ in the female (\%).

Ptychadena bibroni (Hallowell, 1845) (Figure 2 : J 2)

Characterized by 4 pairs of dorsal folds along the vertebral column, the second fold starting from the vertebral line is interrupted at mid length, the supratympanal fold merges with the dorsolateral discontinuous fold, presence of a sacral fold. The Snout-Vent Length (SVL) is $58.7 \mathrm{~mm}$ in the male. A specimen was captured in the banana plantations in Akressi.

Ptychadena longirotris (Peters, 1870) (Figure 2 : J 3)

Dorsal glandular folds are narrow (thin) and flattened, lack of dorsolateral line, long supra-tympanal fold, presence of a black band on the flank (from the tip of the muzzle to the belly). The Snout-Vent Length (SVL) is 44.2 to $60.5 \mathrm{~mm}$ in the male $\left({ }^{\lambda}\right)$ and 50.5 to $57.4 \mathrm{~mm}$ in the female ( $(+)$.

Ptychadena mascareniensis (Duméril and Bibron, 1841) (Figure 2 : J 4)

This species is characterized by extensive pediculated webs, 3 pairs of distinct dorsal folds, dark spot extended to the shoulder, male with two lateral vocal sacs in the upper position. The Snout-Vent Length (SVL) is 37 to $47.7 \mathrm{~mm}$ in the male ( $\delta^{\text {) }}$ and 26,7 to $58.2 \mathrm{~mm}$ in the female (ㅇ).

Ptychadena oxyrhynchus (Peters, 1870) (Figure $2: \mathrm{J}$ 5)

This taxon has a very webbed toes, leaving 1 free phalanx on the inner side and the outer side of the 4th toes, the presence of a dark interocular band demarcated between the top of the head and the muzzle, a longer but not wide head with a pointed snout, prominent glandular cords (dorsal and dorsolateral folds). The Snout-Vent Length (SVL) is 40.5 to $60.1 \mathrm{~mm}$ in the male $\left({ }^{1}\right)$ and 42.8 to $70.65 \mathrm{~mm}$ in the female ( $(+)$.

Ptychadena pumilio (Boulenger, 1920) (Figure 2 : J 6) 
Characterized by small pediculated webs, 3 to 4 pairs of distinct dorsal folds, a dark spot at the shoulder, two vocal sacs by side in sub-terminal position. The SnoutVent Length (SVL) is 35.9 to $49.2 \mathrm{~mm}$ in the male ( $\widehat{0})$ and 40.2 to $65.15 \mathrm{~mm}$ in the female (q).

\section{Family Pyxicephaliidae Bonaparte, 1850}

\section{Genus Aubria Boulenger, 1917}

Aubria subsigillata (Dumeril, 1856) (Figure $2:$ K)

The presence of two rounded femoral glands in an intermediate position between the knee and the cloaca, the translucent belly with round whitish spots are the characteristics of this species. The Snout-Vent Length

\section{CONCLUSION}

The Anuran surveyed in the three agro-industrial zones made it possible to identify 28 species divided into 12 genus belonging to 10 families. The family Ptychadenidae is the most diversified with 6 species. They are followed by Hyperoliidae and Phrynobatrachidae both having 5 species each. Arthroleptidae and Bufonidae comprising of 4 species and 3 species respectively. Dicroglossidae, Hemisotidae, Pipidae, Pyxicephaliidae and Ranidae are the least diversified with one (1) specie each. Three

\section{ACKNOWLEDGEMENT}

Our profound gratitude goes to Mr GUEYE Paul and Mr OUNGBE Franck for their contribution to the capture of

\section{REFERENCES}

Adeba PJ, Kouassi P \& Rödel MO., 2010. Anuran amphibians in a rapidly changing environment -revisiting Lamto, Côte d'Ivoire, 40 years after the first herpetofaunal investigations. African Journal of Herpetology $59: 1-18$.

Assemian NE, Kouamé NG, Tohé B, Gourène G, Rödel MO., 2006. The anurans of the Banco National Park, Côte d'Ivoire, a threatened West African rainforest. Salamandra $42:$ : 41-51.

Blé CY, Djeni NDT, Dadié A, Cissé M, Yobouet BA, Djé KM, Fantodji A., 2016. Prévalence et potentiel de virulence in vitro de Aeromonas sp. Chez la grenouille comestible Hoplobatrachus occipitalis (Ranidae) collectée dans le Centre Ouest de la Côte d'Ivoire. International journal of Innovation and Applied Studies, 18(2) : 502509.

Bridges CM \& Semlitsch RD., 2000. Variation in pesticide tolerance of tadpoles among and within species of Ranidae and patterns of
(SVL) is 70.8 to $78 \mathrm{~mm}$ in the male $(\hat{\delta})$ and 71.6 to $81.7 \mathrm{~mm}$ in the female (우).

\section{Family Ranidae Rafinesque-Schmaltz, 1814 \\ Genus Amnirana Dubois, 1992}

Amnirana albolabris (Hallowell, 1856) (Figure 2 : L)

This species is marked by the presence of a dorsolateral fold, an oval-shaped suprabrachial gland on each shoulder in the male, anterior limbs stretched right forward, the carpal joint does not reach the end of the muzzle (in males) or slightly exceeds. The SnoutVent Length (SVL) is 31.5 to $56.55 \mathrm{~mm}$ in the male (ठ) and 48.50 to $71 \mathrm{~mm}$ in the female (P).

unidentified species have also been inventoried: Artroleptis sp, Sclerophrys sp and Phrynobatrachus sp. It appears also 6 species are common to all the three plantations and banana plantations respectively. These results will serve as a reference for further investigations on the Anuran and the development of appropriate measures to ensure better protection and sustainable exploitation of Anuran fauna in Côte d'Ivoire.

Anuran in the three agro-industrial zones of South-East Côte d'Ivoire.

amphibian decline. Conservation Biology 14(5) : 1490-1499.

Channing A, 2001. Amphibian of Central and Southern Africa. Cornell University Press, Ithaca, New York. 17-25.

Frétey T, Dewynter M. \& Blanc C-P., 2011. Amphibiens d'Afrique centrale et d'Angola. Clé de détermination illustrée des Amphibiens du Gabon et du Mbini, Biotope, Mèze (Collection Parthénope), Muséum national d'Histoire naturelle, Paris, $232 \mathrm{p}$.

Hoyos-Hoyos JM, Isaacs-Cubides P, Devia N, GalindoUribe DM \& Acosta-Galvis AR., 2012. An approach to the ecology of the herpetofauna in agroecosystems of the Colombian coffee zone. South American Journal of Herpetology $7(1)$ : 25-34.

Konan JCBYN, Kouamé NG, Kouamé AM, Gourène ABA, Rödel MO., 2016. Feeding Habits of Two Sympatric Rocket Frogs ( Genus Ptychadena) 
in a Forest Remnant of Southem-Central Ivory Coast West Africa. Entomol Omithol Herpetol 5: 176

Kouamé NG, Konan JCBYN, Adepo-Gourène $A B$, Gourène G, Rödel MO., 2014. The amphibians of Yakassé-Mé village forest, à threatened rainforest of south-eastern Ivory Coast. Herpetology Notes 7 : 657-665.

Kouamé NG, Ofori-Boateng C, Adum GB, Gourène G, Rödel MO., 2015. The anuran fauna of a West African urban area. Amphibian \& Reptile Conservation 9 : 1-14.

Kpan TF, Adeba JP, Kouamé NG, Koné I, Kouassi KP, Rödel MO., 2014. The anuran fauna of a Volunteer Nature Reserve: the Tanoé-Ehy Swamp Forests, south-eastern Ivory Coast, West Africa. Zoosystematics and Evolution 90 : 261-270.

Lamotte M, 1967. Le problème des Ptychadena (Fam. Ranidae) du groupe mascareniensis dans l'ouest Africain.Bulletin du Muséum National d'Histoire Naturelle, 2e series, 39 : 647-656.

Lecointre G \& Le Guyader H., 2006. Classification phylogénétique du vivant. 3eme édition, Berlin, $560 \mathrm{p}$.

Neveu A, 2004. La ranaculture est-elle une alternative à la récolte? Etat actuel en France INRA. Production Animale 17 : 167-175.

Menin M, Santos RS, Borges RE, Piatti L, 2015. Notes on the diet of seven terrestrial frogs in three agroecosystems and forest remnants in Northwestem Sao Paulo State, Brazil. Herpetology Notes 8 : 401-405.

Nzigidahera B, 2005. Note sur Hoplobatrachus occipitalis (Günther, 1859), espèce comestible au Burundi. Bulletin Scientifique de I'Institut National pour l'Environnement et la Conservation de la Nature, Série 1 : 1-7.

Rödel MO \& Branch WR., 2002. Herpetological survey of the Haute Dodo and Cavally forests, western Ivory Coast. Stuttgarter Beiträge zur Naturkunde, Serie A 620 :1-31.
Rödel MO \& Ernest R., 2003. The amphibians of Marahoué and Mont Péko National Parks, Ivory Coast. Herpetozoa 16 : 23-29.

Rödel MO \& Ernest R., 2004. Measuring and monitoring amphibian diversity in tropical forests. I an evaluation of methods with recommendations for standardization. Ecotropica $10: 1-14$.

Rödel MO \& Spieler M., 2000. Trilingual keys to the savannah-anurans of the Comoé National Park, Ivory Coast. Stuttgarter Beiträge zur Naturkunde, Serie A 620 :1-31.

Rödel MO, 2000a. Herpetofaune of West Africa, Vol. I: Amphibians of the West African savanna. Edition Chimaira Frankfurt/M. 335p.

Rödel MO, 2000b. Les communautés d'amphibiens dans le Parc National de Taï, Côte d'Ivoire. Les anoures comme bio-indicateurs de l'état des habitats. In Girardin, O., Koné, I \& Tano Y (eds). Etat de recherches en cours dans le Parc National de Taï (PNT), Sempervira, Rapport de Centre Suisse de la Recherche Scientifique, Abidjan 9. pp 108-113.

Rödel MO, 2003. The amphibians of Mont Sangbé National Park, Ivory Coast. Salamandra 39: 91-112.

Semlitsch RD, 2000. Principles for management of aquatic-breeding amphibians. The Journal of Wildlife Management, 615-631.

Sinsch U, 1991. Mini-review: the orientation behaviour of amphibians. Herpetological Journal, 1(54) : $1-544$.

Vallan D, 2000. Influence of forest fragmentation on amphibian diversity in the nature reserve of Ambohitantely, Madagascar. Biological Conservation 96(1): 31-43.

Tohé B, Assemian NE, Kouamé NG, Gourène G, Rödel MO., 2008. Déterminisme des coassements des Anoures de la ferme piscicole du Parc National du Banco (Côte d'Ivoire). Science et Nature (1): 71-79. www.amphibia.web.org: dernière consultation le 20 juillet 2018. 